\title{
Need to evaluate the performance of real-time PCR assays for the quantitation of cytomegalo- virus DNA load in lower respiratory tract specimens
}

\author{
María Ángeles Clari ${ }^{1}$, Estela Giménez ${ }^{1}$, Gerardo Aguilar ${ }^{2}$, Isabel Corrales ${ }^{1}$, Juan Alberola ${ }^{3}$ and David Navarro ${ }^{1,3^{*}}$
}

There is an increasing appreciation for the potential clinical value of the quantitation of cytomegalovirus (CMV) DNA in the lower respiratory tract in critically ill patients lacking canonical immunosuppression, in view of the possible pathogenic role of CMV in these patients [1]. No data have been published on the analytical performance of real-time PCR assays for this purpose.

We present our data on the performance of the COBAS $^{\circ}$ AmpliPrep/COBAS $^{\circ}$ TaqMan CMV PCR Assay (Roche Diagnostics, Mannheim, Germany) for the quantitation of CMV DNA in tracheal aspirates (TA). This CMV PCR assay has been approved recently by the US Food and Drug Administration for use with plasma specimens [2]. We chose TA for the analyses because of the simplicity of their collection in critically ill patients undergoing mechanical ventilation.

We pooled TA obtained from five ICU patients with undetectable CMV DNA levels in TA and in plasma specimens [3]. The pool was fluidized by treatment with $N$-acetyl cysteine (1\% in PBS) at a $1: 1$ volume ratio (vortexed for 30 seconds, incubated for 10 minutes at room temperature and centrifuged at $1,600 \mathrm{rpm}$ for 10 minutes). The pellet was then resuspended with distilled water to obtain the initial volume. Four aliquot portions were spiked with different quantities $\left(2.69,3.69,4.69\right.$, and $\left.5.69 \log _{10} \mathrm{IU} / \mathrm{ml}\right)$ of the First World Health Organization International Standard for CMV (National Institute for Biological

\footnotetext{
* Correspondence: david.navarro@uv.es

'Microbiology Service, Hospital Clínico Universitario, Institute of Research INCLIVA, Av. Blasco Ibáñez 17, 46010, Valencia, Spain

${ }^{3}$ Department of Microbiology, School of Medicine, University of Valencia, Av. Blasco Ibáñez 17, 46010, Valencia, Spain

Full list of author information is available at the end of the article
}

Standards and Control, Hertfordshire, UK) [4]. The testing pools were assayed in heptuplicate on three consecutive days.

The fitted regression line between copies $/ \mathrm{ml}$ and $\mathrm{IU} / \mathrm{ml}$ for tracheal aspirates was $y=1.0013 x-0.0517$ $\left(R^{2}=0.999\right)$. According to our calculations, 1 copy $/ \mathrm{ml}$ was equated to $0.90 \mathrm{IU} / \mathrm{ml}$ (similar to that for plasma specimens [5]). The overall intra-assay and inter-assay coefficients of variation were $8.2 \%$ (95\% confidence interval (CI), -0.6 to $17.0 \%)$ and $10.77 \%$ (95\% CI, 1.69 to $19.8 \%$ ), which are slightly higher than those for plasma specimens [5]. The analytical performance of the assay was analyzed with clinical samples containing different copy numbers of CMV DNA. The data are shown in Table 1 . The overall intra-assay and inter-assay coefficients of variation were $14.0 \%$ (95\% CI, 9.8 to $18.1 \%$ ) and $15.4 \%$ (95\% CI, 12.1 to $18.8 \%)$, respectively.

Our data indicate that this CMV PCR assay performs well with fluidized TA containing low to intermediate CMV DNA loads (between 500 and 50,000 copies $/ \mathrm{ml}$ ), and may therefore be used for monitoring CMV replication in the lower respiratory tract in critically ill patients undergoing mechanical ventilation.

\section{Abbreviations \\ Cl: Confidence interval; CMV: Cytomegalovirus; PBS: Phosphate-buffered saline; PCR: Polymerase chain reaction; TA: Tracheal aspirates.}

\section{Competing interests}

DN has received honoraria from Roche Diagnostics for participating in several conferences. The remaining authors declare that they have no competing interests.

\section{Acknowledgements}

The authors are grateful to Roche Diagnostics for providing the reagents used in the current study. 
Table 1 Performance of the cytomegalovirus PCR assay for quantitation of cytomegalovirus DNA load in tracheal aspirates

\begin{tabular}{llll}
\hline Group (number of specimens) & Range of CMV DNA loads (copies/ml) & \multicolumn{2}{l}{ \% Coefficient of variation (95 \% confidence interval) } \\
\cline { 3 - 4 } & & Intra-assay & Inter-assay \\
\hline A (10) & 150 to 851 & $14.0(9.8$ to 18.7$)$ & $15.4(12.1$ to 18.8) \\
B (10) & 1,234 to 8,781 & $10.6(7.8$ to 14.0) & $16.2(11.2$ to 21.5$)$ \\
C (10) & 11,013 to 56,000 & $11.7(4.9$ to 18.5$)$ & $12.8(7.3$ to 18.3$)$ \\
A + B + C (30) & 150 to 56,000 & $14.0(9.8$ to 18.1) & $15.4(12.1$ to 18.8) \\
\hline
\end{tabular}

CMV PCR assay, COBAS $^{\oplus}$ AmpliPrep/COBAS ${ }^{\oplus}$ TaqMan Cytomegalovirus PCR Assay (Roche Diagnostics, Mannheim, Germany). ${ }^{\mathrm{a}}$ Tracheal aspirates were obtained from 20 patients with septic shock of abdominal origin admitted to the ICU. On the basis of their cytomegalovirus (CMV) DNA content, the specimens were grouped into three categories: A, between 150 and 1,000 copies $/ \mathrm{ml} ; \mathrm{B}$, between 1,000 and 10,000 copies/ml; and C, >10,000 copies/ml. The specimens were divided into the above referred groups based on two criteria: the precision of the Roche PCR assay for plasma specimens was shown to vary depending upon the CMV DNA content - in this sense, the coefficient of variation was maximum for specimens containing $<1,000$ copies $/ \mathrm{ml}$, minimum for those containing $>10,000$ copies/ml, and intermediate for specimens containing CMV DNA loads between 1,000 and 10,000 copies/ml [5]; and the majority of tracheal aspirates from critically ill patients displaying an episode of active CMV infection contain CMV DNA loads $<1,000$ copies/ml, so the knowledge of the performance of the PCR assay with specimens containing CMV DNA loads within this range (150 to 1,000 copies $/ \mathrm{ml})$ is of particular clinical interest. Only occasionally, tracheal aspirates contain $>10,000$ copies $/ \mathrm{ml}$. ${ }^{b}$ As determined by the CMV PCR assay. This PCR assay targets the CMV UL54 gene (DNA polymerase) and displays a limit of detection of 100 copies $/ \mathrm{ml}(91 \mathrm{lU} / \mathrm{ml})$, a limit of quantification of 150 copies $/ \mathrm{ml}(164 \mathrm{lU} / \mathrm{ml})$, and a linear quantification range from 150 to $10,000,000(2.18$ to $7.0 \mathrm{log} 10)$ copies/ml for plasma specimens.

\section{Author details}

Microbiology Service, Hospital Clínico Universitario, Institute of Research INCLIVA, Av. Blasco Ibáñez 17, 46010, Valencia, Spain. ${ }^{2}$ Surgical Intense Care Unit, Hospital Clínico Universitario, Institute of Research INCLIVA, Av. Blasco Ibáñez 17, 46010, Valencia, Spain. ${ }^{3}$ Department of Microbiology, School of

Medicine, University of Valencia, Av. Blasco Ibáñez 17, 46010, Valencia, Spain.

Published: 19 Nov 2013

\section{References}

1. Kalil AC, Florescu DF: Prevalence and mortality associated with cytomegalovirus infection in nonimmunosuppressed patients in the intensive care unit. Crit Care Med 2009, 37:2350-2358.

2. Hirsch HH, Lautenschlager I, Pinsky BA, Cardeñoso L, Aslam S, Cobb B, Vilchez RA, Valsamakis A: An international multicenter performance analysis of CMV viral load tests. Clin Infect Dis 2013, 56:367-373.

3. Chilet M, Aguilar G, Benet I, Belda J, Tormo N, Carbonell JA, Clari MA, Costa E, Navarro D: Virological and immunological features of active cytomegalovirus infection in nonimmunosuppressed patients in a surgical and trauma intensive care unit. J Med Virol 2010, 82:1384-1391.

4. Fryer JF, Heath AB, Anderson R, Minor PD: Collaborative Study Group: Collaborative Study to Evaluate the Proposed $1^{\text {st }}$ WHO International Standard for Human Cytomegalovirus (HCMV) for Nucleic Acid Amplification (NAT)-based Assays. In WHO ECBS Report 2010, WHO/BS/ 10.2138. Geneva: WHO Press; 2010.

5. $\mathrm{COBAS}^{\otimes}$ TaqMan $^{\circledR}$ CMV Test FDA Approved Package Insert. Roche Diagnostics: Mannheim; 2012.

\section{$10.1186 / \mathrm{cc} 13119$}

Cite this article as: Clari et al:: Need to evaluate the performance of realtime PCR assays for the quantitation of cytomegalovirus DNA load in lower respiratory tract specimens. Critical Care 2013, 17:465 